\title{
Magical Realism and Intertextuality in Selected 20th Century American Ethnic Novels
}

\author{
Prof.Assoc. Dr. Tidita Abdurrahmani \\ Faculty of Philology and Education,
}

Department of Educational Sciences

Bedër University, Tirana, Albania

\begin{abstract}
The focus of this contribution is on the elements of magical realism and intertextuality in 20th century American Ethnic Novels. To some critics a text is just a palimpsest or tablet that has been written upon or inscribed two or three times. The other texts having been perfectly erased and remaining still partly visible. To this trait is associated even the idea that the intertext is a general field of anonynymous formulae, of unconscious or automatic quotations. Given without quotation marks. Sometimes attention to the character of intertextuality goes so far as to argue that the reader's own previous readings, experinces and position within the cultural formation also form a cruxial intertext. An in depth reading and analysis of John Barth, Thomas Pynchon, Irving Howe and Michael Kohler presented in this paper aims at proving proof to the widely held belief that intertextuality is the parasite that dwells within every postmodern text, especially American Postmodern literature. On the other hand unlike the fantastic or the surreal , magical realism presumes that the individual requires a bond with the tradition and the faith of community, that he or she is historically constructed and connected. The elements employed in magical realism are not completely fantastical and unearthly, they are just part of another culture and are dismissed by our rational Western minds as unreal and inpossible integral part of their reality. To put back together shattered cultural fragments through storytelling, often implies to remember, that is to put oneself , ones identity back together. The magical realism elements in Rudolf Anaya, Ralph Ellison. Leslie Marmon Silko and Thomas Pynchon show that this technique is the most adopted stylistic effect of relating the postmodern world to the preserved and revisisted cultural and historical traditions of the ethnic americans.
\end{abstract}

Keywords: Magical Realism and Intertextuality in Selected 20th Century American Ethnic Novels

\section{Introduction: Intertextuality and Magic Realism Definitions}

Derived from the Latin "intertexto", meaning to intermingle while weaving, intertextuality is a term first introduced by the French semiotician Julia Kristeva in the late sixties. A literary work, then, is not simply the product of a single author, but of its relationship to other texts and to the structures of language itself. "[A]ny text," she argues, "is constructed of a mosaic of quotations; any text is the absorption and transformation of another" (Kristeva 1964:37).Another definition is that provided by "A Glossary of Literary Terms" Abrahams M.H. in which intertextuality appears as "A relation in between two texts which has an effect upon the way in which the intertext (that is the text within which other texts reside or echo their presence) is read." (Abrahams 1981:56).Yet dictionaries and glossaries do not just limit themselves to providing definitions about intertextuality as a literary term, they even plunge into the unfolding of the characteristics and categorizations of intertextuality. One of the traits of the concept of intertextuality is that it subverts the concepts of a text as a self-sufficient, hermetic totality, foregrounding the fact that all literary production takes place in the presence of other texts.

One can not speak of intertextuality without himself falling victim of it. Julia Kristeva refers to the literary phenomenon of 
intertextuality as a permutation of texts:"In the space of a given text, several utterances taken from other texts intersect and neutralize one-another"(Kristeva 1964:79). According to John Frow on the other hand the text "has not only an intertextual relationship to previous texts, but also an intertextual relationship to itself as a canonized text.(Frow qtd in Abrahams 1981:79).While, according to John Barth literature has reached a point of "exhaustion" as there exists the "dread that the precursors have told all the stories, exhausted the genres, used up the very language available for artistic creation."(Barth 1967:30).

The only way out of the vicious circle of intertextuality according to Roland Barthes seems to be acknowledging the death of the author and avoiding the possibility of something new.On the other hand he defines intertextuality as a phenomenon bringing together a new tissue of past citations:"bits of code, formulae, rhythmic models, fragments of social language pass into the text and are redistributed within it for there is always language before and around the text."(Barthes qtd. in Abrahams 1981:120). To summarize the whole we can say that intertextuality has to be seen in association with the texts referred to along the work and the whole complex issue of the reader's varied expectations.

It was Franz Roh, who in the mid 1920's introduced the term magic realism into the artistic discourse It was brought all along by him as "Magischer Realismus" a countermovement in art in which "the charm of the object was rediscovered". The essays generally agree that magic realism is a mode suited to exploring and/or transgressing boundaries, it often facilitates the fusion or co-existence of possible worlds, spaces, systems that would be irreconcilable in other modes of fiction.

By including a plurality of worlds magic realist texts posit themselves on territory between or among these worlds--in phenomenal and spiritual regions where trasformation, metamorphosis and dissolution are common.Some characteristics of magic realism include:1)intentional creation and incorporation of alternative spaces, 2)juxtaposition of natural and supernatural worlds, 3)clash of different semiotic domains, 4)inclusion of different world-views and cosmologies 5)distortion of cyclical time, 6)mirroring of past and present astral and physical planes 7)extensive use of sensory details,and of symbols and imagery 8)incorporation of legend and folkore and 9)presentation of events from multiple perspectives.

Unlike the fantastic or the surreal, magic realism presumes that the individual requires a bond with the traditions and the faith of community, that he/she is historically constructed and connected. The elements employed in magic realism are not completely fantastical and unearthly, they are just parts of another culture and are dismissed by our rational Western minds as "unreal" and impossible integral part of their reality. To put back together shattered cultural fragments through storytelling, often implies to remember, that is, to put oneself, one's identity back together.

In America by inscribing specific indigenous belief systems in the narrative, authors recreate cultural practices that radically differ from Western paradigms based on a separation of culture and nature, phenomena and consciousness, the natural and the supernatural. The hallucinations and impressions which man receives from his environment tend to become reality, especially in cultures with a determinate religious and cultish background.

\subsection{Intertextuality Examples}

On my way to finding out examples of intertextuality researches have been running across texts which are distinguished for their marked use of this device and others which make use of it in a less frequent and subtle way, but which nevertheless can not escape being haunted by the presence or the echo of other texts within them. The device of intertextuality is more widely used in texts like The Crying of the Lot 49, Thomas Pynchon, and "The Literature of Exhaustion" John Barth ,but it comes out in a subtler way even in "Mass Society and Postmodernization".

\subsubsection{Intertextuality in The Crying of the Lot 49, Thomas Pynchon}

The Crying of the Lot 49 has been defined as Pynchon's most accessible work, though also one of his densest. There are many cultural,technical,scientific and historical references packed into less than 200 pages of the novel.It is a labyrinth of references and details and parodies which lead, according to some, toward /or away from meaning and structure.In presenting a postmodern reality in which the genre and discipline borders are blurred or shifted, people are becoming more and more machine-controlled and the continuous flow of information is leading to an ever more puzzling chaos and 
multiplicity of choices, the author has taken references from the world of literature, that of science,media etc, by in this way making intertextuality one of the most widely used devices in the novel. Once at Echo Courts, Oedipa is accompanied to her room by Miles, a 16 year-old drop-out manager with Beattle haircut, singing a song which is perhaps indirectly meant to court her:

\title{
Too fat to Frug
}

That's what you tell me all the time,

When you really try'nto put me down

\author{
But l'm hip
}

So close your big fat hip (Pynchon 1965:16)

Another intertextuality is the quoting of the song the Paranoids keep singing while Oedipa and Metzger are consuming their love relationship, and watching everything from the window of the hotel room. In the same context, when Metzger, the lawyer has reached Oedipa's room, on TV. is running Cashiered, a movie in which Metzger had been starring as a young boy in the role of Baby Igor. Pynchon succeds in creating an inter-media atmosphere where the action of the movie runs parallely to the developing of the action in Echo Courts Room and the novel."Listen, Listen , here's where I sing"......(In the movie Baby lgor is singing)

Gainst the Hun and Turk, never once do we shirk,

My daddy, my doggie and me

Through the perilous years, like the three Musketeers

We will stick just as close as can be (Pynchon 1965:19)

An instance of intertextuality is even the informal advertisment Oedipa finds on the grafiti covered walls of one bathroom, where the outgoing guy invites girls to get in touch with him, but only through the Waste system. The mentioning of this system as an alternative postal service, as well as the occurrence of the sign of muted horn beneath it, will be the initial clues of a series of ever more puzzling clues and hints concerning the Tristero system:"Interested in sophisticated fun?You,hubby,girl friends. The more the merrier.Get in touch with Kirby, through Waste only, Box 7391,L.A"(ibid 38).The most genuine example of Pynchon's marked intertextuality is the incorporation of verses from The Courier's Tragedy, a play wose scenarios and characters are meant to parallel Oedipa's quest and her encounter with different facets of the American reality.In the third act of the play Pasquale plots to do away with young Nicolò by suggesting a game of hide-and -seek and by then making him crawl inside an enormous canon:

\section{Out in a bloody rain to feed our fields}

\section{Amid the Maenad roar of the nitre's song}

\section{And sulfur's cantus firmus (ibid 50)}

This technique of Thomas Pynchon is repeated throughout the book, alluding to almost all the chapters of the play. Oedipa's desperate search for hints even where they do not exist, leads her into envisioning clues of the Tristero even in the historical marker of the Fangoso Lagoons:"On this site in 1853, a dozen Wells, fargo men battled galantly with a band of masked marauders in mysterious black uniforms"(ibid 71). When Oedipa fails to find the so much-sought responses to her questions concerning the Tristero even in an article issued by Bibliothéque des Timbrophiles of Jean Bapiste Moens "Did the organization enter the penumbra of historical eclipse.From the battle of Austerlitz until the difficulties of 1848, the Tristero drifted on, deprived of nearly all the noble patronage"(ibid 142), she recurs to a stamp auction. Oedipa's knowledge 
of stamps and of physics, including the Maxwell Demon machine, is an act of subtle intertextuality, even though the scientific knowledge mentioned in the book is not provided by means of quotations marks.

In the dark 15 $\phi$ dark green from the 1893 Columbian Exposition Issue, the faces of three courtiers, receiving the news at the right hand side of the stamp, had been subtly altered to express uncontrollable fright.In the $3 \phi$, Mothers of America Issue, put on the Mother's day, 1934, the flowers to the lower left of Whistler's mother had been replaced.(ibid 144).

\subsubsection{Intertextuality in "The Literature of Exhaustion", John Barth}

Since the beginning of his essay, while unfolding in front of us the issue meant to be treated in his work, John Barth, provides us with insights about his special concern with intertextuality. The intermedia arts, the in-depth consideration of another author's literary career, and the treatment of the literature of exhaustion, all make us predict the degree of intertextuality of Barth's own essay. He starts with a quotation from Jorge Luis Borges Labyrinths "Every writer creates his own precursors . His work modifies our conception of the past, as it will modify the future"(Barth 1980:19) and then goes on with another quotation by himself. What attracts the attention of the readers at first glimpse is the graphic presentation of the beginning of the text:the name and surname of the author have not been capitalized on purpose(the author wants to show that, no author can any longer hold the exclusivity, and the brand of originality),the quotation from Lost in the Funhouse has been graphically represented by gaps(without the literature of its predecessors, the creation of any author would sound nonsense).

Although himself not commiting a pure instance of intertextuality Barth starts by considering the intermedia arts, themselves a form of trans-medium intertextuality."Robert Filliou's "Ample food for stupid thought" is a box full of postcards on which are inscribed apparently meaningless questions to be mailed to whomever the purchaser judges them suited for"(ibid 20). On the surface this document is a catalogue, but in any case the wares are lively to read about and make for interesting conversation in fiction writing classes. Later on Barth commits a double-intertextuality when he quotes excerpts from Borges' "intertextuality based -text" Pierre Menard, Author of the Quixote. According to Barth, the hero, a sophisticated turn-ofcentury French symbolist produces, not copies or imitates, but composes several chapters of the Servantes novel.By juxtaposing instances of the same text as excerpted respectively from the Borges and Servantes texts, Barth, ironizes the claim of many authors that they have produced new literature, when in fact they have just unfairly copied parts, or ideas of their predecessors works.

Barth goes on mentioning another much anthologized story of Borges "Tlon, Uqbar,Orbis Tertius".Characteristic of this story is that here we encounter the phenomenon of intertextuality twice or thrice removed.It is a story about the invention of a secret society of scholars who elaborate its every aspect in a surreptitious encyclopedia, The First Encyclopedia of Tlon.So Borges on his side makes reference to the Encyclopedia of Tlon ,a probably non-existent text written by an anonymous writer, and Barth refers to Borges by at the same time referring even to the anonymous writer of the encyclopedia.The network of intertextuality, and the realization of the "exhaustion of literature" goes even further, when while going through "a footnote to a scholarly edition of Sir Thomas Browne"(ibid 26),Barth comes upon a perfect Borges datum reminiscent of Tlon's self realization, "the actual case of the book called The Three Impostors alluded to in Browne's Religio Medici among other places "(ibid 26).So within a paperback edition of a book one can trace more than three instances of intertextuality, or of marked referentiality (The Encyclopedia of Tlon, The Three Impostors, Religio Medici).

Another instance of intertextuality appears through the essay when Barth mentions Borges' frequent allusions to the 602nd night of The 1001 Nights, when owing to a copyists error, Scheherezade begins to tell the story from the beginning.Borges considers it as an instance of a story-within a-story turned back upon itself, and if we consider it from the point of view of what this story constitutes for Barth, we can name it as a bifold intertextuality. Finally Barth tries to summarize Borges' stance by quoting the considerations of other critics regarding his literary career and his style, and by in this way commiting another act of intertextuality.In the words of one of his editors"For (Borges)no one has claim to originality in literature, all the writers are more or less faithful amanuenses of the spirit, translators and annotators of pre-existing archetypes"(Borges qtd. in Barth 1980:30).It is worth emphasizing the fact that whenever Barth quotes something from Borges, he does not identify that quotation by title of the book, publication place, edition etc.So according to Barth, there is no original literature and even Borges' inclination to write brief comments on imaginary texts, adds overtly to the corpus literature. The major intertextuality in this essay is the continuous allusion to Borges that Barth makes all along. 


\subsubsection{Intertextuality in "Mass Society and Postmodern Fiction", Irving Howe}

In order to actualize the situation of fiction in the modern and the postmodern society the author starts with the story of Raskolnikov (lying on his bed despondent, the landlady has planned to have him evicted, he has received a letter from his mother telling him that his sister is going to marry an old man just for the sake of money and he has already visited the old pawnbroker and measured the possility of murdering her.Written by Dostoyevsky, the story together with the accurate content of the letter have been extracted from "The Partizan Review“ edition of 1959 and comprise a clear instance of intertextuality."It is my pleasure to infom you, on behalf of the Gugenheim Foundation, that you have been awarded a fellowship for the study of colour imagery in Pushkin's poetry and its relation to the myths of the ancient Muscovites"(Howe 1970:3). Even the content of the letter itself seems to make clear reference to intertextuality as a device.

In speaking about a group of novelists who have chosen to write about the American experience by choosing subjects and morals that have been removed from that very experience, Irving Howe quotes some evaluations from a film critic who regards the post-war writer's experience as one of ambushing rather than as one of accurate reflection: "The writer who wants to let go, has figuratively to leave the urban and suburban and either go abroad, or go into the past, or go into those few pockets of elemental emotional life left in the country"(ibid 5) Regarding the San Francisco fathers as a reflex of the circumstances of mass society, Howe quotes Paul Goodman who states that "they have the theory that to be factless, not to care, is the ultimate rebellion, but this is a fantasy ;for right under the surface is burning shame, hurt feelings, fear of impotence." (ibid 139).

If we stick to the postmodern idea advocated by John Barth, that no literature is original literature, we would go on saying that even Howe's mentioning of D.H.Lawrence, Norman Mailer,Wright Morris, Nelson Agren ect. is an act of intertextuality, though not a traditional "quotation based" one.Yet the routes of postmodernism are limitless and Howe ends with another quotation of Faulkner's The Hamlet" I can't stand no more.....this case is adjourned" (ibid 7). One can never expect to find relief and solace of interpretation in a postmodernist text.

\subsubsection{Intertextuality in "Postmodernismus Ein begrieffsgeschichtlicher Uberblick", Michael Köhler}

In his article Michael Köhler traces the development in American criticism of the concept of "postmodernity" and discusses the relative merit of the various definitions it received. In trying to juxtapose the different definitions emanating with regards to the term,the author shows instances of intra-lingual intertextuality. The explanation and expounding of the definitions or the critical statements are in most of the cases made in German, while the quoted definitions excerpted from dictionaries or encyclopedias are in English: "Das bestreitet auch ein Gegner des Begriffs wie Philip Stevick nicht:"Postmodernist is an epithet that I, for one,find annoying and unhelpful.But it is true,all the same,that recent fiction no longer orients itself according to its own relations to the modernist masters. (Kohler, Michael p.9)"

\section{Magic Realism Illustrations}

\subsection{Magic Realism in House Made of Dawn}

In The House Made of Dawn Momaday reveals the psychological situation of a man who is lost between two worlds, torn apart culturally and spiritually, and drifting toward death. Abel is "reeling on the edge of the void," but he does not fall. The very moment when Abel seems to have exhausted all the possibilities of finding redemption he holds the seed to his ultimate recovery. Magic realism in The House Made of Dawn comes out through the countless episodes typical of Indian cosmology, the techniques and the imagery adopted by the author.If we consider that the prevailing themes of the book are the healing force of nature and the existence caught between two worlds, this may be sufficient to provide us with an insight about the magic realism elements of the book.

The opening chapter is marked by a series of flashbacks, while in the second chapter Momaday abandons a continuous plot line and operates instead with a device resembling the cutting technique employed in film. Without any apparent logical connections, fragmentary scenes from Abel's past alternate with blurred perceptions of his immediate environment. The intensity of the images, the apparent disjunction of time elements, and the surface illogic-all typical of dreams and hallucinations-account for the haunting, nightmarish effect of some chapters as well as for the development of the magic 
realism elements.Dream-like elements are added to the story especially through the chapter "Priest of the Sun" in which the narrative voice is centered in Abel's consciousness as he is lying, delirious from alcohol and the brutal beating he received from Martinez.

The magical elements of the novel start from the very title and from the very first chapter. At the opening of House Made of Dawn, Momaday introduces Abel, the protagonist, saying that Abel is running through a desolate landscape by himself. The landscape is "the house made of dawn, made of pollen and of rain."(Momaday 1999:79). Such a house, in which the wall is the dawn and whose roof is the rain, is a place that is limitless and free. Abel is born into this freedom, and he is the one who has the responsibility to tend to the natural world around him, to take care of it and foster it. In one of the episodes of the novel when Abel decides to run we know that he is probably incapable of running far, as he is still recovering from the severe injuries he sustained in Los Angeles. Yet the most credible explanation is that he is figuratively running with the ancestors in an attempt and promise to look back to their tradition and to preserve them.

In another episode of the novel, the saintly Santiago is depicted on his ride southward into Mexico. According to Father Olguin, Santiago had disguised himself as a peon and won a contest at the royal court. As his prize he wed one of the king's daughters. The king tried to have Santiago killed, only to be thwarted by the same rooster, which Santiago pulled out of his mouth whole and alive. The rooster gives Santiago a magic sword that he used to slay the king's assassins. Typical of the Indian cosmology are also the ceremonials.In the episode of the killing of the albino, huge festivities rage through the town as a storm sets in towards the evening. Francisco has spent the evening in the ceremonial kiva, or hut, along with the other holy men in town. Additionally, a bull is running through the streets as part of the ceremony.It is that night that Abel kills the albino and watches his blood drip in the rain.

The basic magic realism of the story is created through Abel's being situated in between two cultures:the world of his grandfather, a world of seasonal rhythms, a land with creatures traditions and ceremonies reaching back thousands of years, and the urban world of post-war white America.Even though it was the war that severed Abel's connections to the "house made of dawn" the world of spiritual and physical wholeness and connectedness to the land, he is able to come back and rediscover his identity.

Remarkable is the relation of the tribes to the weather and the natural phenomena. Their impersonation in nature, comprises a great part of the magic realism of the novel.Francisco teaches his grandsons, Abel and Vidal, to observe the sun. He tells them that:

they must know the long journey of the sun on the black mesa, how it rode in the seasons and the years, and they must live according to the sun appearing, for only then could they reckon where they were, where all things were, in time. (173)

It is worth mentioning here the connection of the tribes to the moon.The moon's reappearance after her three-day "death" has traditionally been read as a symbol of rebirth.Momaday uses a number of devices to reinforce further the connection between Abel and the moon. In two instances the course of the moonlight on the water functions as a bridge, and in the following passage a flock of birds serves as a link:

Then they [the birds] were away, and he had seen how they craned their long slender necks to the moon, ascending slowly into the far reaches of the winter night.They made a dark angle on the sky, acute, perfect; and for one moment they lay out like an omen on the bright fringe of a cloud.(105)

The natural elements also serve as forecasting and predictive devices in the hands of the supersticious tribes.When Francisco listens to the fields and sounds around him, what he hears often foreshadows an event relating to Abel. Likewise, several nights before Abel's murder of the albino Francisco hears "whispers [rising] up among the rows of corn"(56) and cannot put his finger on what the whispers mean until later, when he becomes conscious of an "alien presence close at hand."(59).In most tribal cultures the body is considered to be the shelter of the soul and as such, when the soul becomes corrupted, the body mirrors the whole and the individual undergoes purgation or initiation rituals. In The House Made of Dawn physical disintegration is the outward sign of Abel's inner conflict: "[now] his body was mangled and racked with pain. His body, like his mind, had turned on him; it was his enemy."(89). 
Purgation, otherwise called catharsis is the cleansing of individuals or community of rebellious tendencies. Such a ceremony could have given to Abel the opportunity to vent his agression and avoid killing the albino.Abel does not undego a real initation rite, but the beating Abel receives results from his attempt to get even with Martinez, who has tyrannized him, incite him and Momaday to bring in front of us some aspects of the initiation procedures. As it is common for initiates to be placed into a shallow grave, Abel is "lying in a shallow depression in which there were weeds and small white stones and tufts of long grey grass."(88).

His numerous injuries point to his symbolic death, the knocking out of teeth and the amputation of fingers being common initiatory tortures:"His hands were broken, and he could not move them. Some of his fingers were stuck together with blood, and the blood was dry and black; . .there was blood in his throat and mouth.(91).

Magic realism in the novel unfolds also through the episodes of grandfather Francisco applying magic portions :"Francisco chanted and prayed; the old man applied herbs and powders and portions and salves, and nothing worked."(89).Five days after Abel's return, the people of Jemez celebrate the game of the Chicken Pull.The Rio Grande Pueblos view the insertion of the rooster into the ground and its subsequent removal as a symbolic representation of planting and reaping. The scattering of the rooster's feathers and blood are representative of rain and are believed to increase the fertility of the land and the success of the harvest.Yet familiar, as he seems to become with the Pueblo traditions and rites Abel can not avoid feeling afraid of witchcraft and its effects.

The different stages that Abel's consciousness and identity shaping go through become clearer through Abel's affiliation with the motions of the silversided fish:

There is a small silversided fish that is found along the coast of southern California. In the spring and summer it spawns on the beach during the first three hours after each of the three high tides following the highest tide.These fish come by the hundreds from the sea. They hurl themselves upon the land and writhe in the light of the moon. They are among the most helpless creatures on the face of the earth.(79)

The fish imagery not only reflects Abel's suffering but also indicates the upward movement in his development after he has become aware of his situation. When Abel raises the energy to fight against and eventually escape the drift towards death, the fish too have found their way back to safety in the depth of the sea:

And far out in the night where nothing else was, the fishes lay out on the black water, holding still against all the force and motion of the sea; or close to the surface, darting and rolling and spinning like lures, they played in the track of the moon.(107)

Once Abel has by means of his subconscious gained insight into the meaning of ritual and the controlling forces in the universe, he is ready to establish a formal union with his tribal heritage through the ceremony of the Night Chant which Ben Benally conducts for him.In doing so, he shows his newfound trust in the effectiveness of Indian ceremonials.Another major step towards restoration and initiation into his tribal culture is Abel's vision of the runners after evil. Dreams and visions have always been of utmost significance in the lives of American Indian peoples.

The runners after evil ran as water runs, deep in the channel, in the way of least resistance, no resistance.His skin crawled with excitement; he was overcome with longing and loneliness, for suddenly he saw the crucial sense in their going, of old men in white leggings running after evil in the night. They were whole and indispensable in what they did; everything in creation referred to them. Because of them, perspective, proportion, design in the universe. Evil was. Evil was abroad in the night; they must venture out to the confrontation; they must reckon dues and divide the world.(91).

The race is connected with the ceremony of clearing the irrigation ditches in the spring. It is an imitation of water running through the channels, a magic bid for the vital supply of rain, and a ritual act to prevent the harvest from being influenced by evil powers. 


\subsection{Magic Realism in The Invisible Man, Ralph Ellison}

Typical of Magic Realism is the extensive use of symbols and imagery and Ellison has achieved this more proficiently than any other person:flowery diction, vivid imagery, and a colorful, but complex sentence structure are the distinguishing traits of his style.Despite all of his use of stylistic elements, the characteristic that makes Ralph Ellison's novel so remarkably unique is his ability to combine such diverse elements as realism, surrealism, folklore, and myth.

Invisible Man is a novel that illustrates the finding of one's identity as being no easy task. The Man has no name; he is anonymous, which parallels with the knowledge of his own individuality.He is extremely vulnerable and susceptible to the influence of several social groups as the ones we can see throughout the novel, which is written and constructed in an episodic fashion.The man is invisible because the other characters in the novel fail to "see"and cannot understand his spiritual identity; rather they see him as an object whose mind and body can be manipulated like clay.Some critics consider the black man to be "the least invisible of all men". The narrator does not realize this about himself until he awakes with amnesia from being injured at the paint factory. Then, suddenly, he is no longer afraid to face the real world. His newfound confidence inspires his passion and begins to do things he never thought possible because no one would ever listen.

The novel takes the character to great lengths until he witnesses a riot and realizes "that even an invisible man has a socially responsible role to play"(Ellison 1995:93). This comes out through the "Battle Royale"where most of the magic realism lies in the unconscious fight that Antonio is involved in while standing up for his ideals and his dignity.

Almost consciousless he could hear a hypnotic voice hazily counting down. He fought for the seemingly golden coins but every time he seemed to grab one his hand would be frantically removed by the others and he would be shifted aside, a boy would flip up in the air like a circus seal, and would land with his back on the charged rug (27)

or

"I was fighting automatically and at the same time worrying about the delivery of the speech... An hypnotic voice said five emphatically." (24-25)

In another dream sequence typical of magic realism his grandfather tells him to open the briefcase and see what is inside. Inside the subsequent envelopes, he finds the message "keep that nigger boy running", a message to the whole black community to go on fighting for their rights. Harsh as the struggle of life may sound, the invisible man always finds the courage to find the beautiful even in the most hideous sides of it. While approaching the ring, he takes a glimpse (or at least dreams) of a beautiful blonde girl, among the naked faces of the spectators: "I wanted at one and the same time to run from the room, to sink through the floor, or to go to her, and cover her from my eyes and the eyes of the others with my body"(20). In the "Epilogue", one of the elements of magic realism is its challenge to the established ideals. According to the "invisible man", reality is as irresistible as a club is and he was clubbed into the cellar before he caught the hint.

When one is invisible good/evil, honesty/dishonesty, shift shapes so that one confuses one with the other. He thinks he was never more hated than when he tried to be honest and never more loved and appreciated than when he tried to justify and affirm someone's mistaken beliefs or when he tried to give his friends the incorrect, absurd answers they wished to hear. He was always trying to go in everyone's way but his own, so after years of trying to adopt the opinions of the others, he finally rebelled "he was an invisible man so he took the cellar and hibernated " (462). The use of hibernation, a wintry dormant state, as a social protest grants fantastical elements and makes us empathize with the spiritual state of the "invisible man". The ancestors, important elements in the African cosmology, come in the novel through the grandfather's advices to the invisible man:

Or did he mean that we had to take the responsibility for all of it, for the men as well as the principle, because we were the heirs who must use the principle because no other fitted our needs. Not for the power or for vindication, but because with the given circumstance of our origin, could only thus find transcendence(462)

In Dr. Bledsoe, the author mostly recurs to social realism to reveal the social determinism that revolves around the existence of the blacks, but still he doesn't fail to include even hints of magic realism. One such instance comes out in the episode 
when Dr.Bledsoe keeps emphasizing that black folk can be powerful only in dark, blackness referring to an abstract state of prejudice and discrimination, or a mysterious shelter for the ancestors, and the invisible man felt that "his grandfather was hovering over (him), grinning triumphantly, out of the dark"(123).

\subsection{Magic Realism In Bless Me Ultima, Rudolf Anaya}

In my consideration of the magic realism in Bless Me Ultima, I have concentrated mainly in "Dieciocho", and some other episodes of the book. Bless me Ultima is a beautiful story of a young boy who becomes a man, who grows up so fast with the help of la grande, Ultima.He goes through so many things, seeing three people he knew either killed or drowned and contemplating all this time whether or not God was really there.The boy's quest for knowledge at an early age and his interaction with characters provided with fantastical powers, accounts for the presence of most magic realism elements in the novel.Besides Antony another major character in the story is Ultima, an old frined of the Marez family,and a curandera ,one who cures with herbs and magic and fights evil away from the Marez family.

From the very first confrontation with Ultima we come to foresee that elements of time travel, sorcery, and confrontation between good and evil will unravel through the story.Only Antonia Marez and Anaya's magic realism dares dreaming such gruesome images as "The human race dies and only the "she-goats and the he-goats" remain (176).(Anaya 1972:88) or "The lake cracked with laughter of madness" and the "ghosts stood and walked upon the shore" (120).He argues with God and the Virgin Mary. He commutes with the dead; the dead ask him for blessings.He is considered to be valiant, and this courage sometimes reflects his curiously precocious nature. He is to be considered courageous because he stands for what he believes is right and he is not afraid to go to extreme measures to protect the people he loves. Being forced into being Catholic leads him into having insights into protestantism, witchcraft and eganism.

Typical of Anaya's magic realism is even the merging of the fantastical with the real, and the questioning of what is widely accepted as sustainable reality: The first thing he wonders about when he witneses Lupito's death is "where was Lupito's soul"(26) and this shows how deep Tony's thoughts are.Already at age seven he thinks on a spiritual level.Even his dreams are witnesses to his spirituality. Adults do not dream of God saying "Vengence is mine"(173) or whether "the baptism water is really holy water" (120). The inclusion of dreams is actually magic realism, a stylistic device that Anaya uses to overwhelm the readers with the themes and to express the meanings of the themes in a more impacted manner.His first dream portrays his insecurity about his identity "Is he a fine vaquero or a farmer priest"(5), he is also confused about which God to believe in The Golden Carp- or the Catholic God "he marvels at the bright golden -pagan god" (114) but at the same time fears "God who could not forgive sinners"(138). At the same time he does not understand evil and good. He does not understand why "god cannot forgive the good Narciso while Virgin Mary can forgive the evil Tenorio?"(173)

Other magic realism elements include: the encounter of Antonio and Ultima with Tenorio Trementina and the three witches, the state of being stuck in between two cultures, the ritual of the Indian torture, the image of blood becoming the river, the blending of the fantastical with earthly crime fiction etc. In "Dieciocho" magic realism elements come out through the challenging of the widely held religious concepts:

Thou are dust and in dust shall return. The body is not important, it is made of ashes, the winds and waters dissolve it and scatter it to the four corners of the earth. What we care most for lasts only a brief lifetime then there is eternity. Millions of worlds are born, evolve and pass away into unnmeasurable skies and there is eternity.l knew that eternity lasted forever, and a soul because of one mistake could spend that eternity in hell (195-196), I saw a frightening truth in his eyes. He was telling the truth!He did not believe that he had ever sinned against God(203).

Even when speaking in religious terms Anaya can not refrain himself from mentioning the magical herbs of the curandera"The confession of Saturdays morning sounded to them like a test. The herbs of the priest smelled to him like those of Ultima "(197).

\subsection{Magic Realism in The Crying of the Lot 49}

Although The Crying of the Lot 49 as a novel is well-known for its marked use of intertextuality,along the way we encounter even some hints of the use of magic realism. One of the otherwordly experiences Oedipa is confronted with on her quest 
is the episode with the awaken-dreaming children.Oedipa responds to the children who are awake imagining that they are dreaming, that they are asleep by rejecting them. She also flees from a situation she simply cannot fathom, the silent agreement that permits the mute dancers not to collide with one-another and to stop in concert. They have a way of communicating that is alient to her understanding:

In Golden Gate Park, she came on a circle of children in their nightclothes, who told her they were dreaming the gathering.But that dream was really no different from being awake, because in the mornings when they got up they felt tired, as if the had been up most night.(96)

In another passage Oedipa listens to Mr.Thoth's tales of false Indians, interspersed with cartoon segments about how on certain days he feels the presence of his God.Mr.Thoth's name is that of the Egyptian god of magic and learning who is pictured as a scribe. Thus he is connected with the writing of wills and through magic, with oracles tries to provide Oedipa with crucial information.Even the sensations Oedipa has in the presence of Thoth are compared to the ones one experiences when we feel surrounded by the magic and witchcraft of a sensitive:"She looked around,spooked at the sunlight pouring in all the windows, as if she had been trapped at the centre of some intricate crystal, and said Me god "(74). One of the traits of magic realism is that interweaves magical and realistic events in that we can sometimes hardly distinguish in between them.So in The Crying of the Lot, the sect of the Scurvhamites are concerned with an orderly universe and the reference to God as being somehow equivalent with a digital computer. Thus God as a supernatural element is merged with a man-made machine, the computer.

\subsection{Magic Realism in Tony Morrison's Paradise}

Toni Morrison's Paradise is said to be written in a difficult, Faulknerian style--with twists, turns, and ghosts.She has also been praised for using magic realism in the style of Gabriel Garcia Marquez. The setting of the story itself is typical of magic realism, Ruby, a fictional town founded by blacks who came West to escape the horrors of Reconstruction. Morrison has given the town's founders a biblical stature, they have been assigned the duty to build an"all black man's paradise"on earth, where neither death ,nor famine or destruction threaten, but they become themselves initiators of a discrimination they were meant to fight, and the assault of the posse on the Convent stands for the bringing of the Ruby reality, from paradisiacal down to earthly terms.

The magical elements of the novel unfold through: the inclusion of the fantastical and witchcraft elements typical of the queer practices of the Convent inhabitants, the introduction of characters who live in between two worlds without easily finding solace in either of them,the distortion of cyclical time, and the presentation of a fantastical setting like that of Paradise.So in the Chapter "Consolata" of the novel, Morrison shows the loud-dreaming in which the members of the Convent got involved

Then they ringed the place with candles.Consolata told each to undress and lie down......She spoke of fruit that tasted the way sapphires look and boys using rubies for dice. Of scented cathedrals made of gold where gods and goddesses sat in pews with the congregation....... That is how the loud dreaming began . How the stories rose in that place. Half-tales and the never dreamed escaped from their lips to soar high above guttering candles, shifting dust from crates and bottles.... In spite of or because their bodies ache, they step easily into the dreamer's tale.... In loud dreaming, monologue is no different from a shriek;accusations directed to the dead and long gone are undone by murmurs of love (Morrison 1997: 263-264).

Further on in the novel while Morrison is writing about the assault and the effects of it she brings in front of us men attacking,murdering some women and scattering others to the winds.Mystical in the story remains the presence of Piedade, a creature coming out of the women's fancies, and haunted minds.Consolata says :

"We sat on the shorewalk.She bathed me in emerald water.Her voice made proud women weep in the street....Piedade had songs that could still a wave, make it pause in its curl, listening to language it had not heard since the sea opened.At night she took the stars out of her hair and wrapped me in its wool.Her breath smelled of pineapple and cashews...(284285).

In the chapter named "Paradise" the Convent members appear as angelic creatures, recognized as dead by the rest of the 
community, and returning to earth in war clothes to ask for the redressal of the injustices.It is only toward the end that Toni Morrison brings clear in front of us the image of shifting grounds, events taking place on earth and in paradise:

"When the ocean heaves sending rhythms of water ashore, Piedade looks to see what has come.Another ship, perhaps, but different, heading to port,crew and passengers, lost and saved, atremble for they have been inconsolate for some time.Now they will rest before shouldering the endless work they were created to do down here in paradise"(318).

Before concluding, it is worth mentioning that there are several fantastical episodes in the story which endow it with elements typical of magic realism such as:the episode where the community members and especially the ambulance man realizes that after the assault all corpses have vanished and all chaos has been swiped away.

\section{Bibliography}

Abrahams, M.H. (1981), A Glossary of Literary Terms, Cornell University,

Anaya, Rudolf (1972), Bless Me Ultima ,Hoboken NY

Barth, John. "The Literature of Exhaustion". The Atlantic Monthly (August 1967): 29-34.

Broich, U. (1997), 'Intertextuality', in Bertens (ed.) (1997). Ellison, Ralph. Invisible Man, Vintage, U.S.A

Fokkema, D. (1997), 'The Semiotics of Literary Postmodernism', in Bertens (ed.)

Howe, Irving "Mass Society and Postmodern Fiction"in the Decline of the New 211-265.

Hutcheon, L. (1988), A Poetics of Postmodernism, London \& New York: Routledge.

Jameson, F. (1993), Postmodernism, or, The cultural logic of late capitalism, 4. print. - Durham: Duke Univ. Press

Kohler, Michael (1977,) "'Postmodernismus': Ein begriffsgeschichtlicher Oberblick," Amerikastudien, vol. 22, no. 1.

Marshall,Brenda. (1992), Teaching the Postmodern: Fiction and Theory, New Yorkand London: Routledge,

Momaday, Scott(1999) House Made of Dawn, Harper Perennial Modern Classics,

Morrison, Toni(1997) Paradise, Alfred Knopf, Canada,

Pynchon, Thomas(1965) The Crying of the Lot, Harper Collins Publishers, 